\title{
Fractional Order PID Controlled Cascaded Re-boost Seven Level Inverter Fed Induction Motor System with Enhanced Response
}

\author{
P. Bhaskara Prasad ${ }^{1}$, M. Padma Lalitha ${ }^{2}$, B. Sarvesh ${ }^{3}$ \\ ${ }^{1,3}$ Department of Electrical and Electronics Engineering, Jawaharlal Nehru Technological University Ananthapur, India \\ ${ }^{2}$ Department of Electrical and Electronics Engineering, Annamacharya institute of Technology \& Sciences, India
}

\begin{tabular}{|c|c|}
\hline Article Info & ABSTRACT \\
\hline Article history: & Recently, Re-boost seven-level inverter has been developed as an alternative \\
\hline Received Apr 4, 2018 & $\begin{array}{l}\text { between Photovoltaic system and single-phase load. DC level is increased } \\
\text { using a re-boost regulator and its output is rehabilitated into single-phase AC }\end{array}$ \\
\hline Revised Aug 23, 2018 & utilizing a seven-level inverter. The re-boost converter is utilized to escalate \\
\hline Accepted Sep 6, 2018 & $\begin{array}{l}\text { the voltage gain. The objective of the suggested closed loop Re-boost Seven } \\
\text { Level Inverter fed Induction Motor (RBSLIIM) system is to enhance the }\end{array}$ \\
\hline Keyword: & $\begin{array}{l}\text { dynamic response of RBSLIIM using FO-P-I-D controller. Simulink models } \\
\text { are developed for P-I and FO-P-I-D controlled RBSLIIM systems. The }\end{array}$ \\
\hline $\begin{array}{l}\text { Boost converter } \\
\text { FO-P-I-D controller }\end{array}$ & $\begin{array}{l}\text { results of P-I and FO-P-I-D based RBSLIIM systems indicate that the voltage } \\
\text { response with FO-P-I-D is superior to P-I controlled RBSLIIM system. }\end{array}$ \\
\hline
\end{tabular}

Multi-level inve

P-I controller

PV cell

Copyright $@ 2018$ Institute of Advanced Engineering and Science. All rights reserved.

\section{Corresponding Author:}

P.Bhaskara Prasad,

Department of Electrical and Electronics Engineering,

Jawaharlal Nehru Technological University Ananthapur,

Ananthapuramu, Andhra Pradesh, India.

Email: bhaskara.papugari@gmail.com

\section{INTRODUCTION}

The extensive use of fossil fuels has resulted in the global problem of greenhouse emissions. Moreover, as the supplies of fossil fuels are depleted in the future, they will become increasingly expensive. Thus, solar energy is becoming more important since it produces less pollution and the cost of fossil fuel energy is rising, while the cost of solar arrays is decreasing.

In particular, small-capacity distributed power generation systems using solar energy may be widely used in residential applications in the near future [1], [2]. The power conversion interface is important to a grid- connected solar power generation systems because it converts the DC power generated by a solar cell array into AC power and feeds this AC power into the utility grid.

An inverter is necessary for the power conversion interface to convert the DC power to AC power [2]-[4]. Since the output voltage of a solar cell array is low, a DC-DC power converter is used in a smallcapacity solar power generation system to boost the output voltage, so it can match the DC bus voltage of the inverter. The power conversion efficiency of the power conversion interface is important to ensure that there is no waste of the energy generated by the solar cell array. The active devices and passive devices in the inverter produce a power loss. The power losses due to active devices include both conduction losses and switching losses [5]. Conduction loss results from the use of active devices, while the switching loss is proportional to the voltage and the current changes for each switching and switching frequency. A filter inductor is used to process the switching harmonics of an inverter, so the power loss is proportional to the amount of switching harmonics. 
The voltage change in each switching operation for a multilevel inverter is reduced in order to improve its power conversion efficiency [6]-[15] and the switching stress of the active devices. The amount of switching harmonics is also attenuated, so the power loss caused by the filter inductor is also reduced. Therefore, multilevel inverter technology has been the subject of much research over the past few years. In theory, multilevel inverters should be designed with higher voltage levels in order to improve the conversion efficiency and to reduce harmonic content and electromagnetic interference (EMI).

Conventional multilevel inverter topologies include the diode- clamped [6]-[10], the flyingcapacitor [11]-[13], and the cascade H-bridge [14]-[18] types. Diode-clamped and flying capacitor multilevel inverters use capacitors to develop several voltage levels. But it is difficult to regulate the voltage of these capacitors. Since it is difficult to create an asymmetric voltage technology in both the diode-clamped and the flying-capacitor topologies, the power circuit is complicated by the increase in the voltage levels that is necessary for a multilevel inverter. For a single-phase seven-level inverter, 12 power electronic switches are required in both the diode-clamped and the flying-capacitor topologies. Asymmetric voltage technology is used in the cascade H-bridge multilevel inverter to allow more levels of output voltage [17], so the cascade H-bridge multilevel inverter is suitable for applications with increased voltage levels.

Two H-bridge inverters with a DC bus voltage of multiple relationships can be connected in cascade to produce a single- phase seven-level inverter and eight power electronic switches are used. More recently, various novel topologies for seven- level inverters have been proposed. For example, a single-phase sevenlevel grid-connected inverter has been developed for a photovoltaic system [18]. This seven-level gridconnected inverter contains six power electronic switches. However, single DC capacitors are used to construct the single voltage levels, which results in that balancing the voltages of the capacitors is more complex. In [19], a seven-level inverter topology, configured by a level generation part and a polarity generation part, is proposed.

There, only power electronic switches of the level generation part switch in high frequency, but ten power electronic switches and single DC capacitors are used. In [20], a modular multilevel inverter with a new modulation method is applied to the photovoltaic grid-connected generator. The modular multilevel inverter is similar to the cascade H-bridge type. For this, a new modulation method is proposed to achieve dynamic capacitor voltage balance. In [21], a multilevel DC-link inverter is presented to overcome the problem of partial shading of individual photovoltaic sources that are connected in series.

Several individual DC blocks configure the DC bus of a full-bridge inverter, where each DC block is composed of a solar cell, a power electronic switch, and a diode[22-24]. Controlling the power electronics of the DC blocks will result in a multilevel DC-link voltage to supply a full-bridge inverter and to simultaneously overcome the problems of partial shading of individual photovoltaic sources. Closed Loop Analysis of Multilevel Inverter Fed Drives[25]. Comparative Analysis of Carrier Based Techniques for Single phase Diode Clamped MLI and Hybrid Inverter with Reduced Components[26].

The above literature does not deal with re-boost converter fed seven-level inverter. There is a requirement to improve the voltage gain in the output of inverter and improve the dynamic performance of the load. This work proposes re-boost converter between PV and seven-level inverter. The above papers do not compare the response of PI and FOPID controlled RBSLIIM systems. This work proposes FOPID controller to improve the dynamic response of RBSLIIM system.

\section{CIRCUIT CONFIGURATION}

\subsection{Existing System}

The block diagram of existing system is shown in Figure 1.The output of the PV is boosted using a boost converter and its output is inverted using a multi-level inverter and fed to the Single phase induction motor.

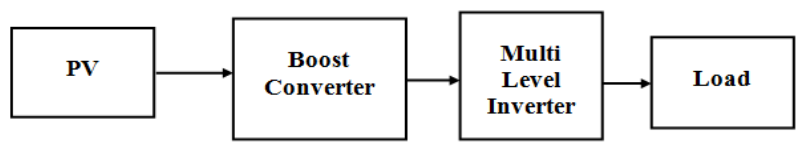

Figure 1. Block diagram of the existing system

\subsection{Proposed System}

The block diagram of proposed RBSLIIM with FOPID controller system is shown in Figure 2. The output of PV is boosted using a re-boost converter and its output acts as one of the input sources of a multilevel inverter. The other input source is given using wind generator. The output of wind generator is

Fractional Order PID Controlled Cascaded Re-boost Seven Level Inverter Fed... (P. Bhaskara Prasad) 
rectified using a rectifier. The output of the rectifier is boosted using a re-boost converter. The output of RBC connected to wind generator acts as the second input of the SLI.

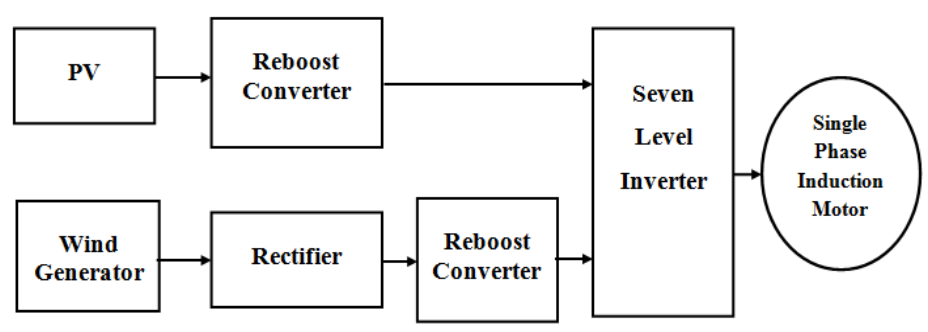

Figure 2. Block diagram of the proposed RBSLIIM system

\subsection{Proposed System with FOPID}

The Closed loop RBSLIIM system with FOPID controller is shown in Figure 3. The speed of induction motor is sensed and it is compared with the reference speed, the error is applied to the FOPID controller for controlling the Reboost converters connected to the seven level inverter.

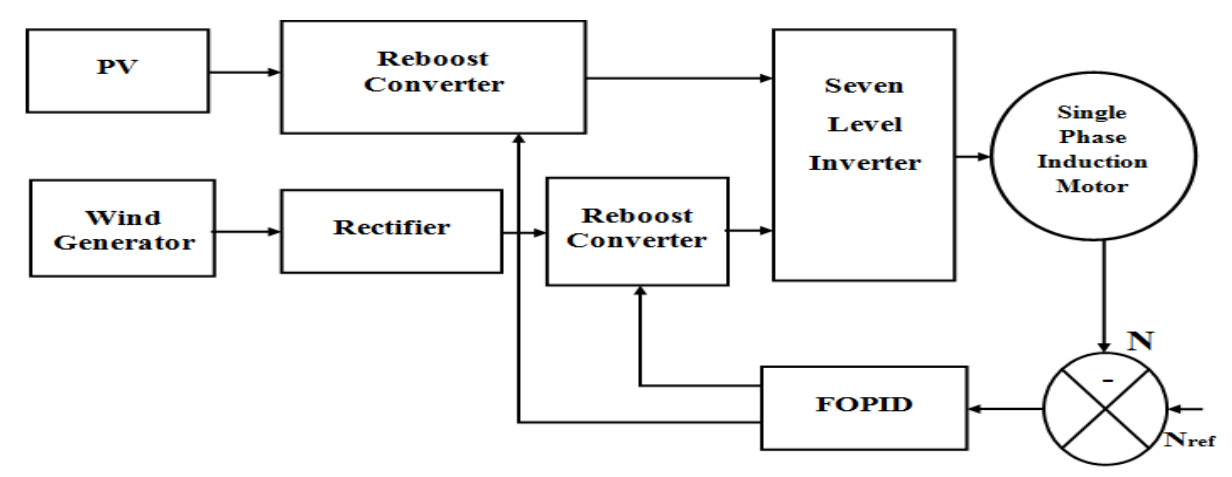

Figure 3. Block diagram of the closed loop RBSLIIM system

\subsection{Reboost Converter Topology}

The reboost converter is a topology with continuous input-current which provides reduced voltage stress. The topology is shown below in Figure 4.

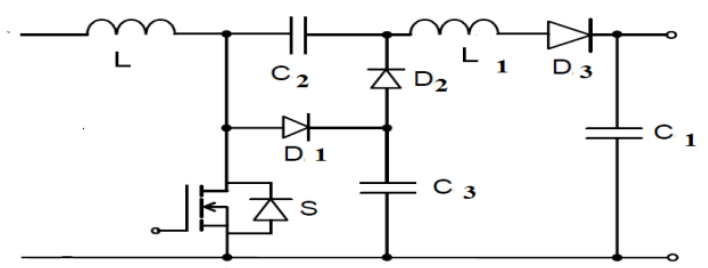

Figure 4. Circuit diagram for reboost converter topology

\subsection{FOPID Controller}

Fractional-order PID (FOPID) controller is a generality of conventional PID controller using fractional calculus. If traditional PID controller is compared with FOPID controller, the order of derivative segment and integral section is non-integer, which provides supplementary litheness in achieving control objectives. Such an FOPID controller given in figure 5 consists of decisive five parameters, i.e. proportional, integral and derivative gains $\{K p, K i, K d\}$, and additionally integration and differentiation orders $\{\lambda, \mu\}$, 
which has a large difference comparing with the conventional PID tuning rules, thus a suitable optimization algorithm is essential to the parameters tuning of FOPID controller.

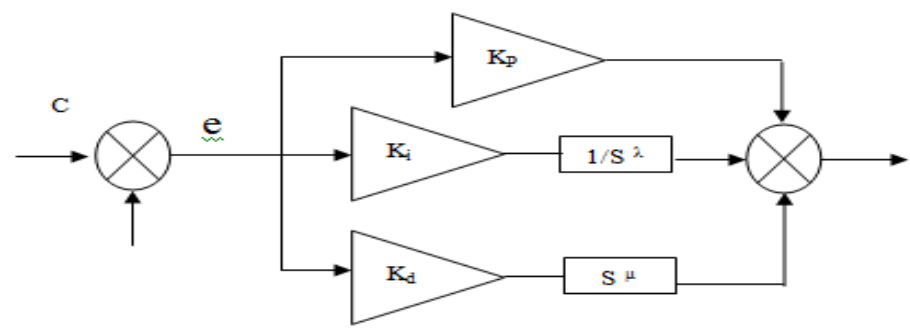

Figure 5. FOPID controller

\section{SIMULATION DIAGRAMS RESULTS AND ANALYSIS}

\subsection{Closed Loop RBSLIIM System with PI Controller}

The Simulink model of Closed-loop RBSLIIM system with PI controller is shown in Figure 6. The output voltage of PV is stepped up using reboost converter. The output of wind generator is rectified and then reboosted. These are the inputs to the MLI. The speed of motor is sensed and it is compared with the reference speed, error is applied to the PI controller. The input voltage from PV and Wind generator is shown in Figure 7 and PV output voltage value is increases from $48 \mathrm{~V}$ to $60 \mathrm{~V}$ at 3.9 seconds due to disturbances. The Output voltage of the inverter is shown in Figure 8 and its value is $210 \mathrm{~V}$. The Motor speed as shown in Figure 9. It is observed that at 3.9 seconds a small decrement in speed and it gradually increases and touches set value at time 4.3 seconds, peak value at 4.6 seconds and settles to at 6.0 seconds. And also the speed oscillates and reaches the set value with an error of $5.3 \mathrm{rpm}$. The torque response is shown in Figure 10 . and its value is $7 \mathrm{~N}-\mathrm{m}$. It can be seen that the speed is regulated using a PI controller.

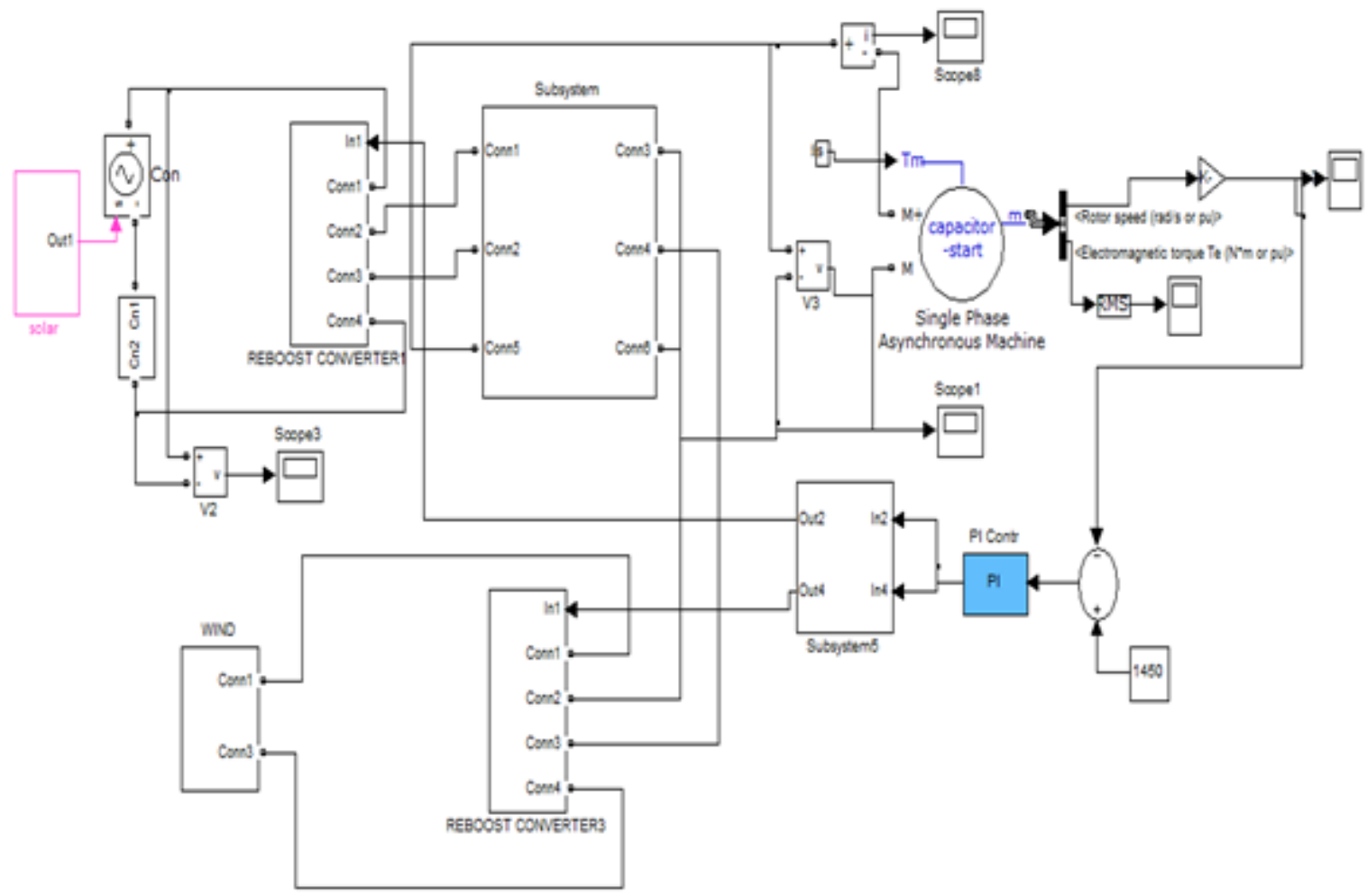

Figure 6. Circuit diagram of the closed loop RBSLIIM system with PI controller 


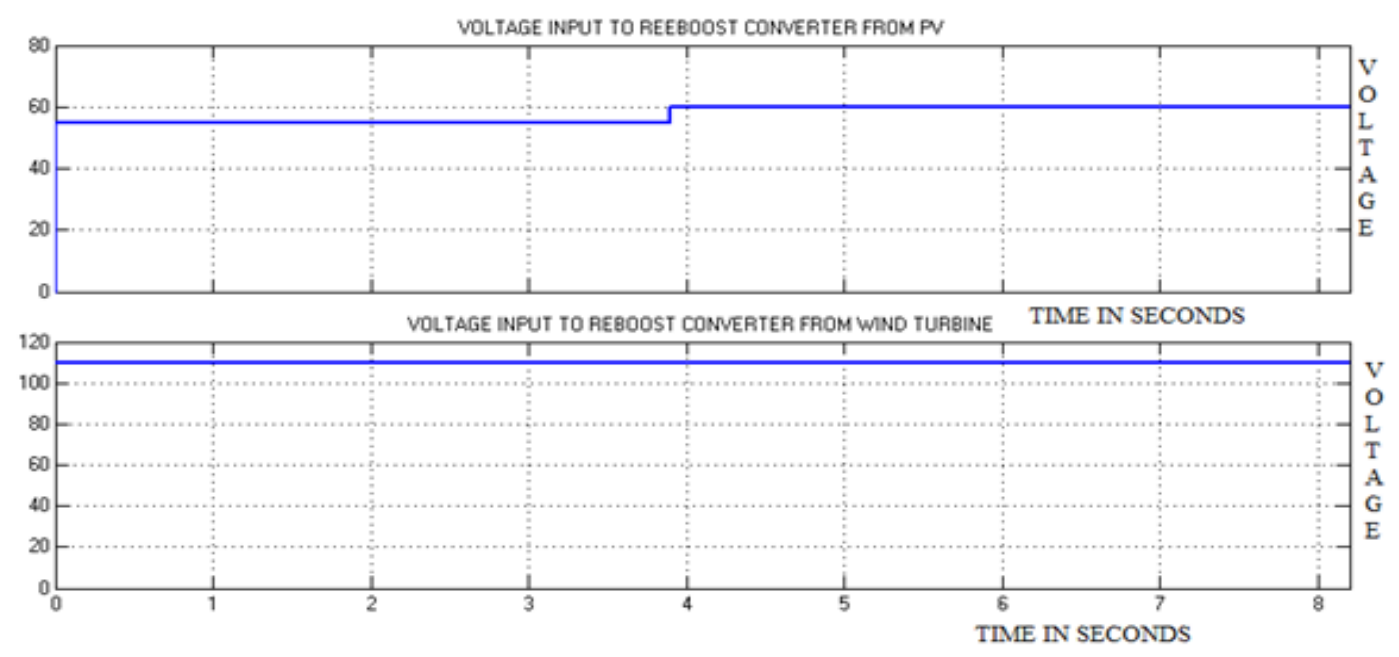

Figure 7. Input voltage waveform to reboost converter

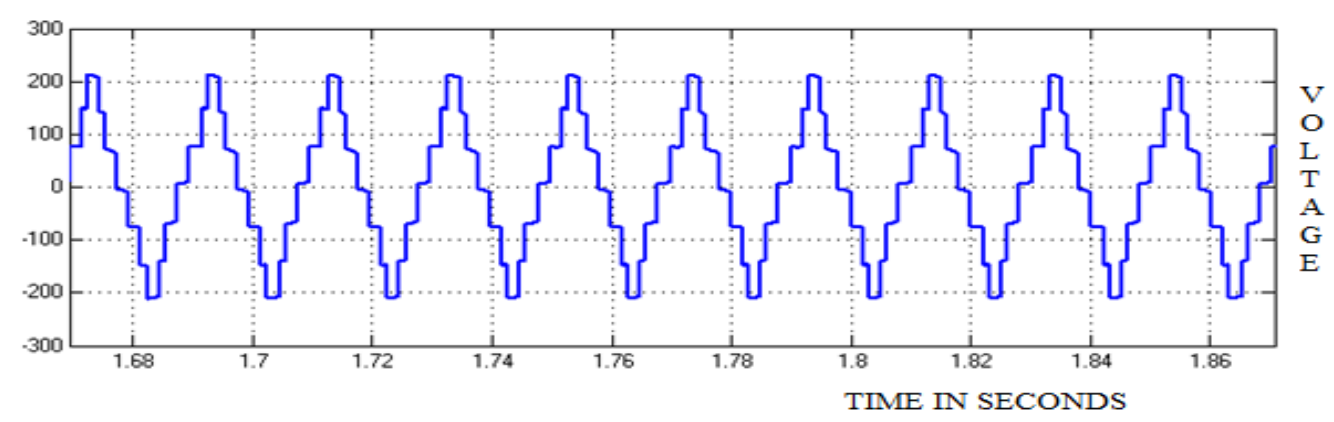

Figure 8. Output voltage waveform of the MLI

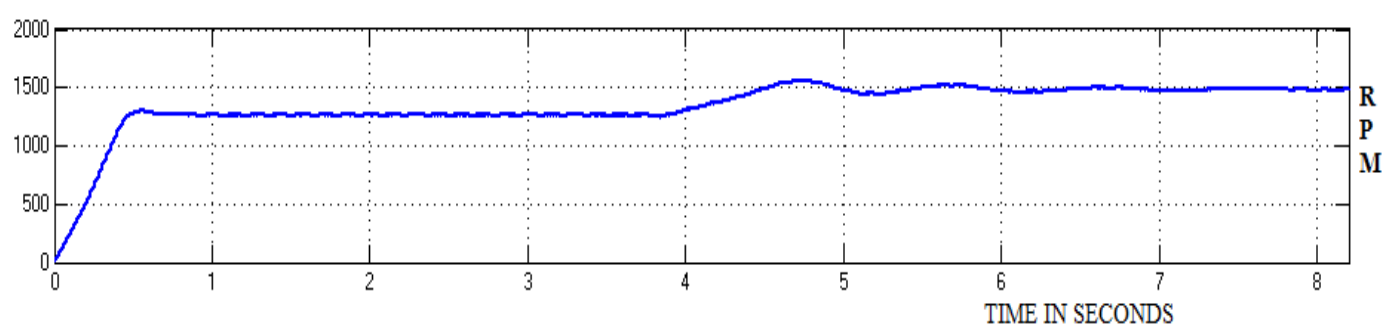

Figure 9. Motor speed of closed loop RBSLIIM system with PI controller

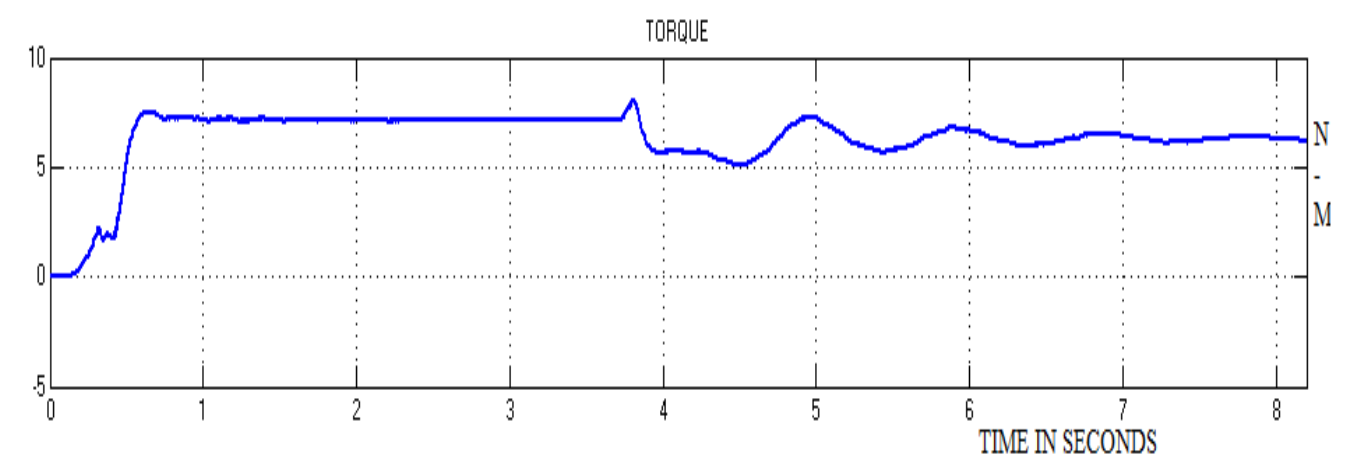


Figure 10. Torque of closed loop RBSLIIM system with PI controller

\subsection{Closed Loop RBSLIIM System with FOPID Controller}

The circuit diagram of the closed loop RBSLIIM system with FOPID controller is shown in Figure 11. As usual the speed of motor is sensed, compared with the reference speed and the error is applied to the FOPID controller. The input voltage to re-boost converter from renewable energy sources is shown in Figure 12 and its value is $60 \mathrm{~V}$ from PV and $110 \mathrm{~V}$ from Wind turbine. The Output voltage of the inverter is disclosed in Figure 13 and its value is $220 \mathrm{~V}$ which is re-boosted from the input voltage of 170V. The motor speed is given in Figure 14. Because of changes in generating end the speed of motor oscillates and settles at 5.0 seconds with an error of $2.6 \mathrm{rpm}$. The amplitude of oscillations is less than that of PI controlled RBSLIIM system. The Torque response is shown in Figure 15 and its value is $7 \mathrm{~N}-\mathrm{m}$. The Comparison of Time-domain Parameters is given in Table 1. It can be noticed that the settling time is reduced from 6.0 to 5.0 second and the steady-state error is reduced from $5.3 \mathrm{rpm}$ to $2.6 \mathrm{rpm}$ using a FOPID controller.

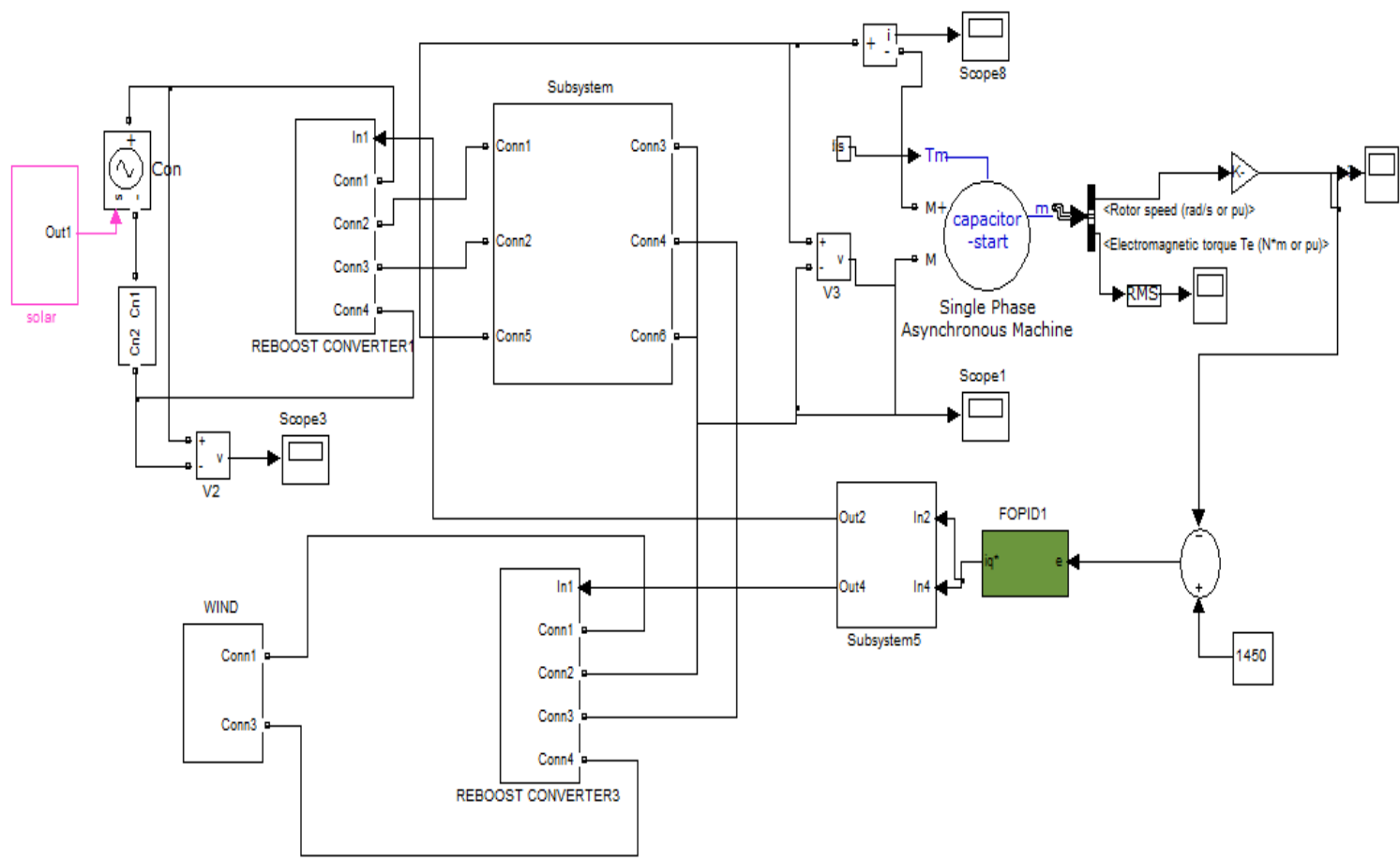

Figure 11. Simulation diagram of the closed loop RBS LIIM system with FOPID controller
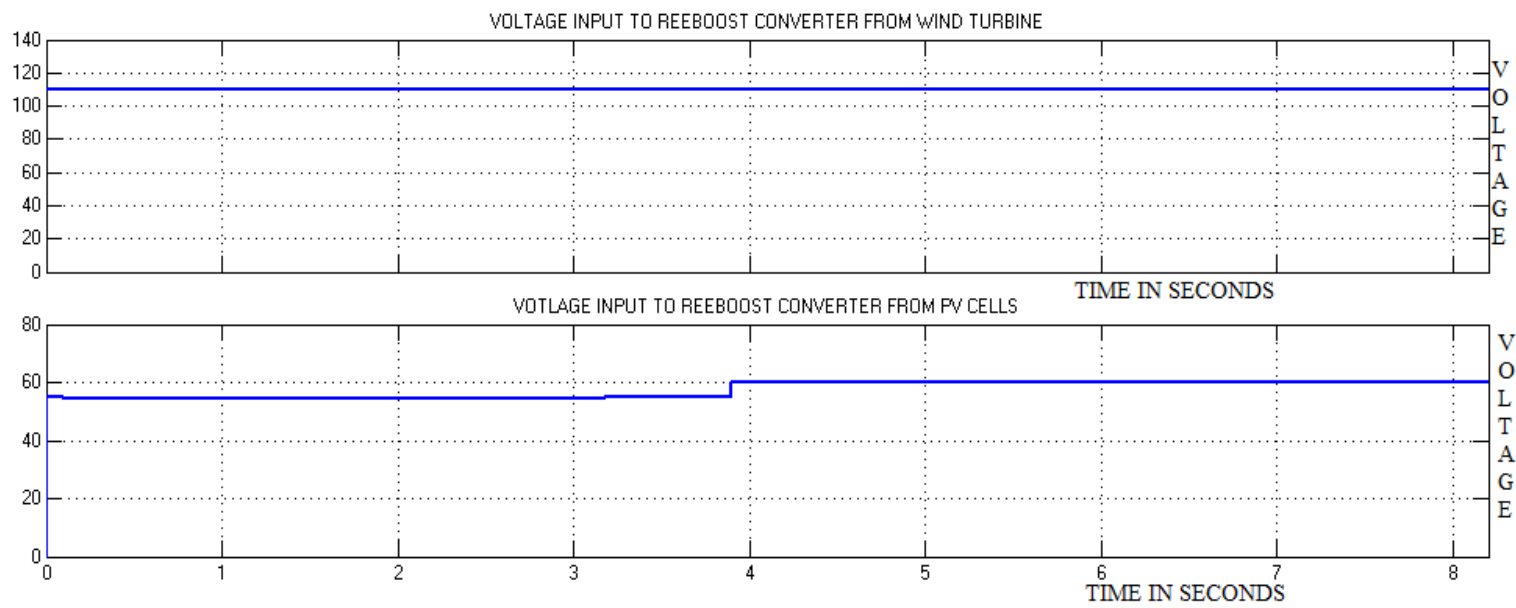

Figure 12. Input voltage waveforms to reboost converter FROM Wind and PV 


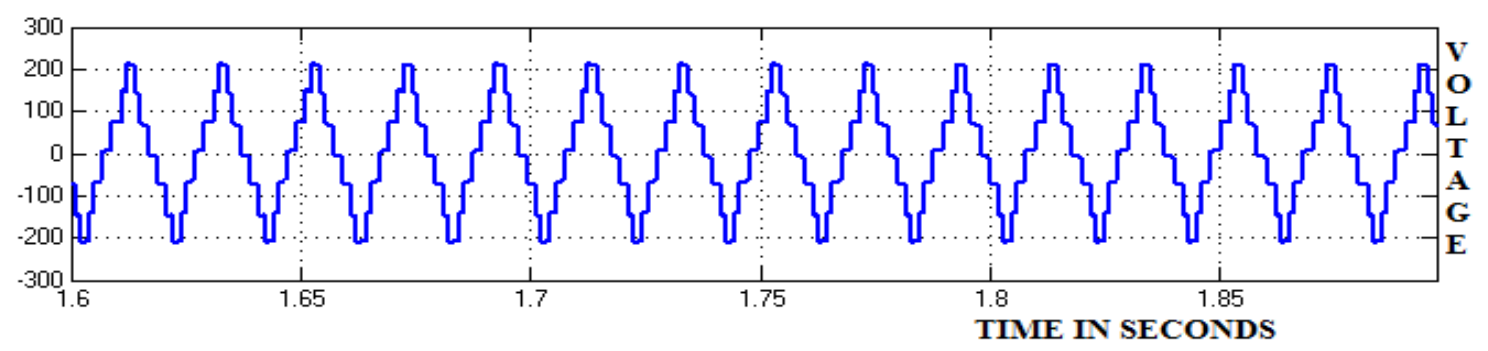

Figure 13. Output voltage waveform of MLI

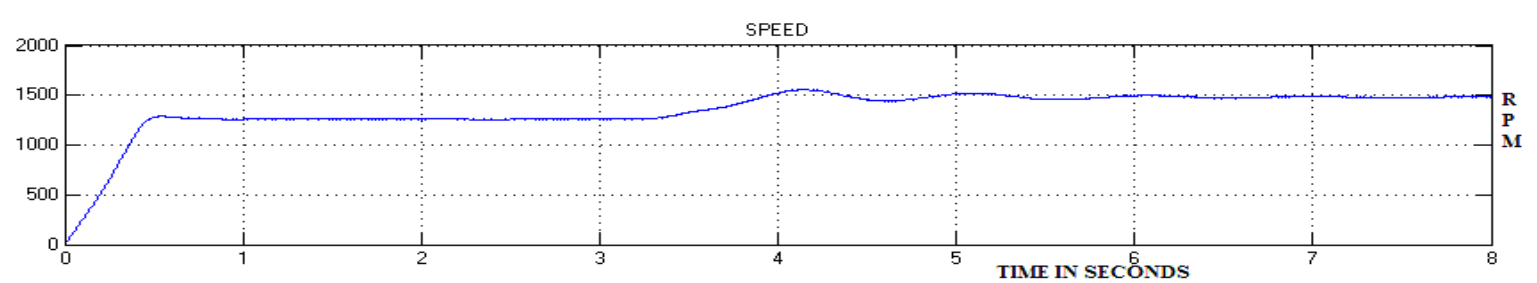

Figure 14. Motor speed of closed loop RBS LIIM system with FOPID controller

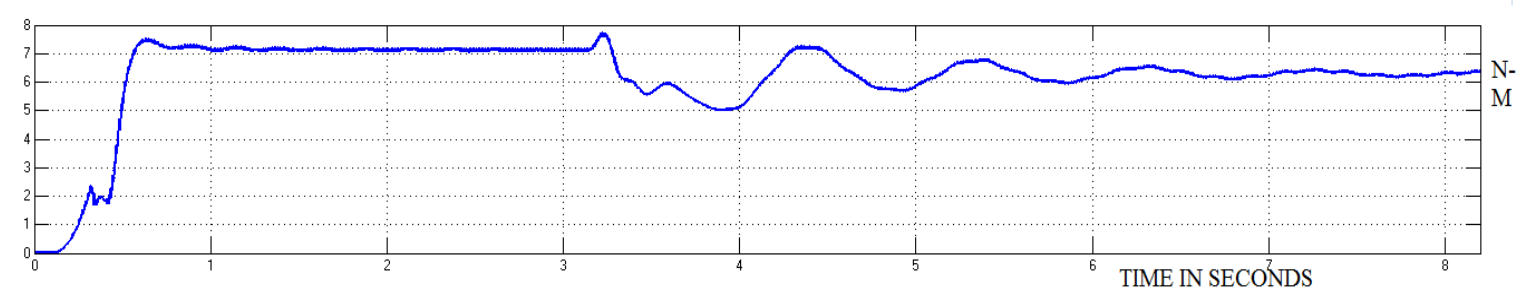

Figure 15. Torque of closed loop RBS LIIM system with FOPID controller

Table 1. Comparison of Time Domain Parameters

\begin{tabular}{ccccc}
\hline Type of Controller & Rise time $(\mathrm{s})$ & Peak time $(\mathrm{s})$ & Setting time $(\mathrm{s})$ & Steady state error (RPM) \\
\hline PI & 4.3 & 4.6 & 6.0 & 5.3 \\
FOPID & 3.9 & 4.2 & 5.0 & 2.6 \\
\hline
\end{tabular}

\section{CONCLUSION}

The PV fed RBSLIIM system is efficaciously demonstrated and simulated. The case studies with P-I and FO-P-I-D-controllers are exhibited in detail. When a disturbance at the input side is generated at 3.9 second it is observed that the settling-time is abridged from 6 seconds in PI controller to 5 seconds in F-O-PI-D controller with decrement in steady-state error of the output from $5.3 \mathrm{rpm}$ in PI Controller to $2.6 \mathrm{rpm}$ when FO-P-I-D controller is replaced with PI controller.Hence there is a percentage decrement in error of 49.05. The results indicate that the FO-P-I-D based RBSLIIM system gives the best dynamic response. The studies indicated that RBSLIIM system is a viable alternative to the existing converters. The benefits of the suggested system are high-voltage gain \& reduced steady-state error. The disadvantage of the recommended system is that it's appropriate for low-power loads.

So finally these type of system when installed in the grids gives best dynamic performance when subjected to sudden changes at input side. The opportunity of the current work is to compare P-I and FO-P-ID based RBSLIIM systems.

In future, work can be extended with proportional resonant controller for RBSLIIM system and checks for better performance. 


\section{REFERENCES}

[1] R.A. Mastromauro, M.Liserre, and A. Dell'Aquila, "Control issues in single-stage photovoltaic systems: MPPT, current and voltage control," IEEE Trans .Ind. Informat., vol. 8, no. 2, pp. 241-254, May. 2012.

[2] Z.Zhao, M.Xu, Q.Chen, J.S.Jason Lai, and Y.H.Cho, "Derivation, analysis, and implementation of a boost-buck converter-based high-efficiency pv inverter," IEEE Trans. Power Electron., vol. 27, no. 3, pp.1304-1313, Mar.2012.

[3] M. Hanif, M. Basu, and K.Gaughan, "Understanding the operation of a Z-source inverter for photovoltaic application with a design example," IET Power Electron., vol. 4,no. 3, pp. 278-287, 2011.

[4] J.-M. Shen, H.L. Jou, and J.C. Wu, "Novel transformer-less grid- connected power converter with negative grounding for photovoltaic generation system, "IEEE Trans. Power Electron., vol. 27, no.4, pp. 1818-1829, Apr. 2012.

[5] N.Mohan, T.M. Undeland, and W.P.Robbins, Power Electronics Converters, Applications and Design, Media Enhanced $3^{\text {rd }}$ ed. NewYork, NY, USA :Wiley, 2003.

[6] K.Hasegawa and H.Akagi, "Low-modulation-index operation of a five- level diode-clamped pwm inverter with a DC-voltage-balancing circuit for a motor drive," IEEE Trans. Power Electron., vol.27, no.8, pp.3495-3505, Aug.2012.

[7] E.Pouresmaeil, D.Montesinos-Miracle, and O.Gomis-Bellmunt, "Control scheme of single-level NPC inverter for integration of renewable energy resources into AC grid, ” IEEE Syst.,vol.6, no.2, pp. 242-253, Jun.2012.

[8] S.Srikanthan and M.K.Mishra, "DC capacitor voltage equalization in neutral clamped inverters for DSTATCOM application," IEEE Trans. Ind. Electron., vol. 57, no.8, pp.2768-2775,Aug. 2010.

[9] M.Chaves, E.Margato, J.F.Silva, and S.F.Pinto, "New approach in back-to-back m-level diode clamped multilevel converter modeling and direct current bus voltages balancing," IET power Electron.,vol.3,no.4, pp.578-589,2010.

[10] J.D.Barros, J.F.A.Silva, and E.G.AJesus, "Fast-predictive optimal control of NPC multilevel converters," IEEE Trans.Ind. Electron.,vol.60, no.2, pp.619-627, Feb.2013.

[11] A.K. Sadigh,S.H. Hosseini,M. Sabahi,and G.B.Gharehpetian ,"Double flying capacitor multi-cell converter based on modified phase-shifted pulse width modulation," IEEE Trans. Power Electron.,vol.25,no.6, pp.15171526,Jun.2010.

[12] S.Thielemans, A.Ruderman, B.Reznikov, and J.Melkebeek, "Improved natural balancing with modified phaseshifted PWM for single-leg five- level flying-capacitor converters," IEEE Trans. Power Electron., vol.27, no.4,pp.1658-1667, Apr.2012.

[13] S.Choiand M.Saeedifard, "Capacitor voltage balancing off lying capacitor multilevel converters by space vector PWM,” IEEE Trans .Power Delivery, vol. 27, no.3, pp.1154-1161,Jul.2012.

[14] L.Maharjan, T.Yamagishi, and H.Akagi, "Active-power control of individual converter cells for a battery energy storage system based on a multilevel cascade pwm converter," IEEE Trans. Power Electron., vol.27, no.3, pp. 1099-1107, Mar.2012.

[15] X.She, A.Q.Huang, T.Zhao, and G.Wang, "Coupling effect reduction of a voltage-balancing controller in singlephase cascaded multilevel converters," IEEE Trans. Power Electron., vol.27,no.8,pp.3530-3543, Aug.2012.

[16] J. Chavarria, D. Biel, F. Guinjoan, C. Meza, and J.J. Negroni, "Energy- balance control of PV cascaded multilevel grid-connected inverters under level-shifted and phase-shifted PWMs," IEEE Trans. Ind. Electron., vol.60, no.1, pp. 98-111, Jan. 2013.

[17] J. PeredaandJ.Dixon, "High-frequency link: A solution for using only one DC source in asymmetric cascaded multilevel inverters," IEEE Trans. Ind. Electron., vol. 58, no. 9, pp. 3884-3892, Sep. 2011.

[18] N. A.Rahim, K.Chaniago, and J.Selvaraj, "Single-phase seven-level grid-connected inverter for photovoltaic system,” IEEE Trans. Ind. Electr., vol. 58, no. 6, pp. 2435-2443, Jun. 2011.

[19] Y. Ounejjar, K. Al-Hadded, and L.A. Dessaint, "A novel six-band hysteresis control for the packed U cells sevenlevel converter: Experimental validation,” IEEE Trans. Ind. Electron., vol.59, no. 10, pp. 3808-3816, Oct. 2012.

[20] J.Mei,B.Xiao,K.Shen, and L.M.JianYongZheng, "Modular multi level inverter with new modulation method and its application to photovoltaic grid-connected generator," IEEE Trans. Power Electronics., vol. 28, no. 11, pp.50635073,Nov.2013.

[21] I.Abdalla, J.Corda, and L.Zhang, "Multilevel DC-link inverter and control algorithm to overcome the PV partials hading," IEEE Trans. Power Electron.,vol.28, no.1, pp.11-18, Jan.2013.

[22] J.M. Shen, H.L. Jou, and J.C. Wu, "Novel transformer-less grid- connected power converter with negative grounding for photovoltaic generation system," IEEE Trans. Power Electronics., vol.27,no.4, pp.1818-1829, Apr.2012.

[23] R.Gonzalez, J.Lopez, P.Sanchis, and L.Marroyo, "Transformer less inverter for single-phase photovoltaic systems," IEEE Trans. Power Electron., vol.22, no. 2,pp.693-697, Mar.2007.

[24] N.Femia, G.Petrone, G.Spagnuolo, and M.Vitelli, "Optimization of perturb and observe maximum power point tracking method,"IEEE Trans. PowerElectronics.,vol.20,no.4, pp.963-973,Jul.2005.

[25] Gopinath "Closed Loop Analysis of Multilevel Inverter Fed Drives ",IJPEDS,2015.

[26] Suseela satish kumar," Comparative Analysis of Carrier Based Techniques for Single phase Diode Clamped MLI and Hybrid Inverter with Reduced Components, IJPEDS,2017 